\title{
PENGGUNAAN METODE TASK-BASED LEARNING UNTUK MENINGKATKAN KETERAMPILAN MENULIS MAHASISWA
}

\author{
Tri Kusnawati \\ Jurusan Pendidikan Bahasa Perancis, FBS Universitas Negeri Yogyakarta \\ Korespondensi: Kampus Karangmalang, Yogyakarta 55281 \\ Pos-el: reallyvc@yahoo.com
}

\begin{abstract}
Abstrak
Penelitian ini bertujuan meningkatkan keterampilan menulis mahasiswa Jurusan Pendidikan Bahasa Perancis FBS UNY melalui penggunaan metode task-based learning dalam pengajaran mata kuliah Expression Ecrite IV. Desain penelitian ini adalah penelitian tindakan kelas yang terdiri atas dua siklus. Pengumpulan data ada tiga jenis, yaitu tes, pengamatan, dan kuesioner. Subjek penelitian ini adalah 15 mahasiswa yang mengikuti mata kuliah Keterampilan Menulis (Expression Ecrite) IV dan pengampu mata kuliah tersebut. Data tentang penggunaan metode pengajaran task-based learning dalam pembelajaran Expression Ecrite yang diperoleh dari observasi dan kuesioner ditafsirkan secara kualitatif, sedangkan data keterampilan mahasiswa dalam menulis ditafsirkan secara kuantitatif. Temuan penelitian ini menunjukkan bahwa penggunaan metode pembelajaran berbasis tugas (task based learning) dalam pembelajaran Keterampilan Menulis IV dapat meningkatkan keterampilan menulis mahasiswa. Peningkatan tersebut terlihat pada pemahaman dan penguasaan materi mahasiswa yang menjadi lebih baik dari sebelumnya. Hal ini dibuktikan dengan peningkatan nilai rata-rata yang diperoleh mahasiswa berdasarkan hasil postes, yakni 6,3 pada siklus I dan 7,2 pada siklus II. Selain itu, terjadi pula peningkatan proses pembelajaran Keterampilan Menulis IV yang ditandai dengan berkurangnya kepasifan mahasiswa dan peningkatan partisipasi mahasiswa dalam kegiatan pembelajaran yang bermakna.
\end{abstract}

Kata-Kata Kunci: Task-Based Learning, Keterampilan Menulis, PTK

\begin{abstract}
This study aims to increase the writing skills of students of French Education Department of Language and Art Faculty of Yogyakarta State University by using the task-based learning method in Expression Ecrite IV teaching. This is a classroom action research project consisting of two cycles. The subjects' of the study were 15 students who took Writing IV (Expression Ecrite IV) including the lecturer. Data were collected using a test, an observation, and a questionnaire. The data of the use of teaching method of task-based learning in Expression Ecrite IV obtained by using an observation and a questionnaire was interpreted qualitatively, while the data of students' learning achievement in writing was analyzed
\end{abstract}


quantitatively. Findings show that the use of learning method of task-based learning in Expression Ecrite IV could increase writing skills of the students. It was shown by the better comprehension and the mastery of materials. It was proven by the increase of the means in the posttest, that were 6.3 in cycle 1 and 7.2 in cycle 2. Besides, there was an improvement of learning process of writing skill IV as indicated by decreasing students' passivity and increasing participation in meaningful learning activities.

Key Words: task-based learning, writing skill, CAR

\section{PENDAHULUAN}

Dalam kehidupan

bermasyarakat, bahasa sebagai alat komunikasi dan sebagai wahana berpikir memegang peranan penting karena segala sesuatu yang dihayati, dialami, dirasakan, dan dipikirkan oleh seseorang hanya dapat diketahui orang lain jika telah diungkapkan dengan bahasa, baik lisan maupun tertulis. Untuk dapat memahami bahasa baik lisan ataupun tertulis, diperlukan berbagai keterampilan berbahasa yang dapat diperoleh melalui pembelajaran bahasa.

Keterampilan berbahasa dalam pembelajaran bahasa meliputi empat jenis keterampilan, yakni membaca, menyimak, berbicara, dan menulis. Berdasarkan aktivitas penggunaannya, keterampilan membaca dan menyimak tergolong keterampilan berbahasa yang bersifat reseptif, sedangkan keterampilan berbicara dan menulis termasuk keterampilan berbahasa yang bersifat produktif.

Dua keterampilan berbahasa yang bersifat produktif, yaitu berbicara dan menulis, memiliki hubungan yang erat. Keduanya merupakan keterampilan berbahasa untuk mengungkapkan pikiran dan perasaan yang ada pada diri seseorang melalui simbol-simbol bahasa. Dilihat dari segi sistem bahasa, baik keterampilan berbicara maupun menulis, memerlukan penguasaan sistem kaidah bahasa. Selain itu, kedua keterampilan ini sama-sama memerlukan penguasaan kaidah-kaidah yang mengatur hubungan antara penutur (pembicara/peneliti) dan penerima (penyimak/pembaca). Dalam berbagai bidang kehidupan misalnya di bidang pendidikan, keterampilan menulis diperlukan. Keterampilan menulis, atau dalam bahasa Perancis disebut Expression Ecrite, merupakan salah satu keterampilan berbahasa yang menjadi tujuan setiap pengajaran bahasa di sekolah maupun di perguruan tinggi. Bagi para mahasiswa, keterampilan menulis merupakan syarat mutlak untuk mencapai keberhasilan perkuliahan, yang selanjutnya juga merupakan kebutuhan praktis setelah lulusan terjun ke dalam lapangan kerja. Menurunnya mutu lulusan perguruan tinggi yang acap kali menjadi isu di dalam masyarakat bukannya tidak mungkin salah satu penyebabnya adalah para mahasiswa kurang menguasai keterampilan menulis.

Seperti keterampilan berbahasa lainnya, keterampilan menulis dapat diperoleh dan dikuasai tidak cukup hanya dengan mempelajari tata bahasa, teori 
menulis, dan menghafal definisi istilah-istilah yang ada dalam bidang karang-mengarang, tetapi juga harus melakukan banyak praktik dan latihan menulis. Tagliante (2008: 135) menyatakan bahwa "Avant de pouvoir écrire pour s'exprimer, pour communiquer avec un destinataire, l'apprenant étranger, bien qu'il sache déjà le faire dans sa langue maternelle, doit apprendre à écrire, à tracer les formes graphiques...", (Sebelum bisa menulis untuk mengungkapkan perasaan atau berkomunikasi kepada penerima pesan, pembelajar bahasa asing meski sudah melakukannya dalam bahasa ibunya, tetap harus belajar menulis, berlatih membuat coretan grafis ...). Jadi, menyusun atau mengorganisasikan suatu gagasan menjadi bahasa tulis yang teratur, sistematis, dan logis bukan merupakan pekerjaan yang mudah, melainkan pekerjaan yang memerlukan latihan dan ketekunan yang terus-menerus, tak terkecuali bagi anggota sivitas akademika seperti mahasiswa. Melalui praktik dan latihan menulis, mahasiswa diharapkan dapat menyusun suatu tulisan, termasuk di dalamnya karangan, dengan baik dan benar. Akan tetapi, pada kenyataannya, berdasarkan pengamatan peneliti selama mengampu mata kuliah Keterampilan Menulis (Expression Ecrite), hanya sebagian kecil mahasiswa saja yang mampu menyusun karangan dengan baik. Hal tersebut terjadi karena terdapat banyak kendala yang dihadapi peneliti selama mengampu mata kuliah tersebut, baik yang berasal dari diri pembelajar maupun dari diri pengajar. Kendala yang berasal dari diri pembelajar di antaranya berupa keterbatasan penguasaan kosakata bahasa Perancis serta keterbatasan penguasaan logis proposisi dan pengaitan antarproposisi tersebut.

Agar tujuan pengajaran keterampilan menulis dapat tercapai dengan hasil yang baik, pengajar dituntut untuk menggunakan metode pengajaran keterampilan menulis yang dapat mendorong minat serta memotivasi pembelajar agar keterampilan menulisnya dapat meningkat. Metode pengajaran yang dapat digunakan untuk meningkatkan keterampilan menulis antara lain adalah pembelajaran berbasis tugas (task-based learning). Dalam metode task-based learning, pembelajar dipacu keinginannya dalam belajar melalui pemberian tugas-tugas yang meliputi listing, ordering and sorting, comparing, problem solving, sharing personal experiences, dan creative tasks. Sayangnya, belum banyak pengajar yang menggunakan metode pembelajaran menulis yang efektif seperti task-based learning.

Berdasarkan uraian di atas, peneliti memandang perlu dilakukan suatu penelitian mengenai "Penggunaan metode task-based learning untuk meningkatkan keterampilan menulis mahasiswa".

Adapun tujuan penelitian ini yakni untuk meningkatkan keterampilan menulis mahasiswa Jurusan Pendidikan Bahasa Perancis FBS UNY melalui penggunaan metode task-based learning dalam pengajaran mata kuliah Expression Ecrite IV.

Menurut Nunan (2005:2), task is an activity or action which is carried out as the result of processing or understanding 
language. Tugas adalah aktivitas atau perbuatan yang terjadi sebagai hasil dari pengolahan atau pengertian bahasa, contohnya menggambar peta setelah mendengarkan tape recorder saat pelajaran mendengarkan. Menurut definisi ini, tugas didefinisikan dalam istilah apa yang akan dilakukan pembelajar di kelas daripada di luar kelas. Tugas biasanya membutuhkan guru untuk menentukan apa yang akan dilakukan untuk menunjang keberhasilan tugas. Penggunaan beragam tugas dalam pengajaran bahasa agar pengajaran bahasa lebih komunikatif.

Lebih lanjut, Nunan (2005:4) mengatakan bahwa "a pedagogical task is a piece of classroom work that involves learners in comprehending, manipulating, producing or interacting in the target language while their attention is focused on mobilizing their grammatical knowledge in order to express meaning, and in which the intention is to convey meaning rather than to manipulate form". Tugas pedagogis merupakan bagian dari kegiatan di kelas yang dilakukan pembelajar dalam memahami, memanipulasi, memproduksi atau berinteraksi, dalam bahasa target sementara yang menjadi perhatian mereka lebih terfokus pada pengetahuan gramatikal untuk mengekspresikan makna, dan perhatian itu sendiri untuk mencari makna daripada memanipulasi bentuk. Jadi tugas-tugas tersebut dilakukan dalam pembelajaran bahasa yang lebih mementingkan makna bahwa bahasa adalah alat komunikasi dari pada mementingkan bentuk aturan-aturan tata bahasa. \begin{tabular}{lr}
\multicolumn{1}{c}{ Dalam proses belajar } \\
mengajar yang menerapkan \\
rancangan task-based learning \\
(pembelajaran berbasis tugas),
\end{tabular} pengajar memberikan tugas-tugas yang berupa aktivitas-aktivitas belajar komunikasi dalam bahasa target yang lebih mementingkan makna dari pada bentuk. Tugas-tugas tersebut berorientasi pada tujuan yang hendak dicapai, yakni tujuan komunikatif. Dengan kata lain, perhatiannya lebih ditujukan pada pengertian dan penyampaian makna agar tugas-tugas yang diberikan dapat dilaksanakan dengan sukses ditandai dengan kemampuan pembelajar menggunakan bahasa yang dipelajari untuk berkomunikasi secara wajar seperi dalam kehidupan nyata.

Dalam rancangan task-based learning terdapat sedikitnya enam jenis tugas yang dapat diterapkan (Willis, 2010: 26-27). Jenis-jenis tugas tersebut yakni:

1. Pembuatan Daftar (Listing); secara praktis kegiatan ini berguna untuk melakukan generalisasi terhadap diskusi yang dilakukan pembelajar dalam usaha mencari jawaban atas ide-ide yang muncul. Proses kegiatan ini meliputi dua hal yakni:

a. brainstorming di mana pembelajar membagi pengetahuan dan pengalaman mereka pada teman-teman di kelas atau pada kelompoknya, dan

b. pencarian fakta di mana pembelajar mencari tahu sesuatu dengan bertanya dan merujuk pada buku.

Hasil kegiatan ini berupa draft peta pemikiran (ide). 
2. Pengaturan dan Peryortiran (Ordering and sorting); tugas ini terdiri dari empat proses utama yakni:

a. Mengurutkan (sequencing items); merupakan perbuatan atau peristiwa yang berurutan secara logis atau kronologis;

b. Merangking (ranking items); berhubungan dengan nilai-nilai individu atau kriteria yang spesifik,

c. Mengkategorikan (categorizing items); mengelompokkan sesuai kategorinya, dan

d. Mengklasifikasikan (classifying items in different ways); dilakukan saat pengkategorian tidak diberlakukan.

3. Perbandingan (Comparing); pada umumnya jenis tugas ini meliputi pembandingan informasi yang sama tetapi berasal dari sumbersumber atau versi-versi yang berbeda. Hal ini dimaksudkan untuk mengidentifikasikan tujuan atau maksud yang sama dan/atau yang berbeda. Tugas ini meliputi:

a. Menjodohkan (matching); dilakukan untuk mengidentifikasi hal-hal yang spesifik dan untuk menghubungkannya satu dengan lainnya,

b. Mencari persamaan (finding similarities); dan

c. Mencari perbedaan (finding differences).

4. Pemecahan Masalah (Problem Solving); tugas-tugas pemecahan masalah menuntut pengetahuan intelektualitas manusia dan kekuatan pikiran. Tugas-tugas tersebut menarik dan menyenangkan untuk dipecahkan.
Proses-proses pengerjaan dan waktu yang diberikan sangat bervariasi tergantung pada jenis dan kompleksitas masalah. Masalah-masalah yang dapat diaplikasikan dalam tugas ini berasal dari kehidupan sehari-hari. Masalah-masalah tersebut berupa hipotesis, pendeskripsian pengalaman, membandingkan alternatif pemecahan masalah. Kelengkapan tugas sering berdasarkan pada ekstrak/intisari pemecahan masalah atau penyatuan kunci-kunci pemecahan masalah. Pengklasifikasian diakhiri dengan studi khusus yang lebih kompleks, dan memerlukan pengamatan yang mendalam berdasarkan atas berbagai kriteria-kriteria tertentu, dan sering meliputi pencarian fakta tambahan dan investigasi.

5. Saling Berbagi Pengalaman Pribadi (Sharing Personal Experiences); tugas-tugas ini mendorong pembelajar untuk berbicara lebih bebas mengenai diri mereka dan membagi pengalaman mereka dengan pembelajar lain. Hasil interaksi tersebut berhubungan dengan percakapan mengenai kehidupan sosial. Tugas ini berbeda dengan tugas-tugas lainnya yang secara langsung berorientasi pada tujuan sehingga tugas tipe ini sulit dilakukan dalam kelas.

6. Tugas Kreatif (Creative Tasks); tugas-tugas ini sering disebut projects dan melibatkan kelompok-kelompok pembelajar pada berbagai jenis tugas kreatif yang lebih bebas. Tugas-tugas tersebut juga memiliki lebih banyak tingkat kesulitan 
dibanding tugas-tugas lainnya dan dapat dilakukan pengkombinasian beberapa jenis tugas; misalnya listing, ordering and sorting, comparing dan problem solving. Kemampuan organisasi dan kerja kelompok penting dilakukan demi terlaksananya tugas. Hasil belajar yang dilakukan sangat dihargai dan disukai baik oleh audience maupun oleh pembelajar yang terlibat secara langsung.

Menulis merupakan kegiatan yang dilakukan melalui proses. Demikian pula halnya dalam menulis resume bahasa Perancis. Dalam proses tersebut terdapat empat tahapan yakni (Charnet dan Robin, 1997: 9-10):

1. Observasi Teks (Observation $d u$ Texte); pada tahap ini harus diketahui jenis teks yang akan diresume, apakah teks jurnalistik, sastra, atau administratif. Kemudian perlu diketahui pula apakah pada teks tersebut terdapat judul dan anak judul, apakah terdapat kolom. Terakhir harus pula diketahui bagaimana struktur teks tersebut, apakah terdiri dari beberapa paragraf, apakah terdapat fakta atau kejadiankejadian.

2. Pembacaan Teks secara Global (Lecture Globale du Texte); selama tahap ini disarankan untuk tidak menulis atau membuat garis bawah pada teks. Hal yang harus diketahui dan dapat dijawab setelah membaca teks adalah jenis tulisan (naratif, eksplikatif, informatif, dan sebagainya), masalah yang ditulis, dan hal yang ditekankan pengarang teks.

3. Pembacaan Teks dengan Seksama (Lecture Attentive du Texte); pada tahap ini dapat dibuat catatan mengenai kata kunci dan merumuskannya kembali. Perlu digarisbawahi bahwa pada saat merumuskan kembali teks tidak diperkenankan menggunakan kata-kata yang sama, yang dapat diambil adalah ide teks tersebut saja. Selain itu, perlu pula dicatat kata atau ide kunci dan kata-kata yang mengaitkan proposisi (kata hubung) dan penggunaan punktuasi.

4. Penelitian Redaksi (Rédaction); tahap ini merupakan tahap terakhir dalam pembuatan resume. Saat penyusunan redaksi ini harus pula diperhatikan kata hubung dan punktuasi yang akan digunakan agar resume yang dibuat memenuhi syarat sebuah wacana yang memiliki koherensi, kesatupaduan, dan logis.

Adapun latihan-latihan yang dapat dilakukan mahasiswa adalah sebagai berikut (Charnet dan Robin, 2011: 16 - 63).

1. Kontak Awal dengan Teks

a. Observasi dan Pemahaman Umum Teks. Kegiatan ini meliputi menemukan tipografi yang terdiri dari:

(1) Judul, sub judul, dan anak judul. Judul ditulis dengan cetak tebal, huruf capital, atau dengan huruf kecil namun dengan ukuran yang besar, terletak di kepala artikel atau teks. Sub judul terletak tepat di bawah judul, merupakan penjelasan bagi pembaca. Anak judul terletak di bawah judul atau sub judul, berisi penjelasan berbentuk teks pendek. 
sub judul, dan anak judul.

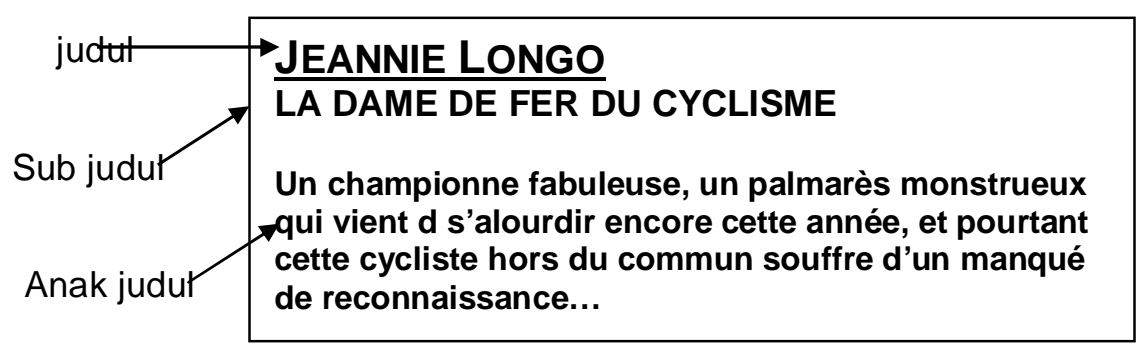

Gambar 1. Contoh Judul, Subjudul, dan Anak Judul

(Charnet dan Robin, 2011: 18)

(2) Penggunaan huruf; huruf besar, cetak tebal, dan cetak miring. Huruf besar sering digunakan untuk memberi nilai lebih pada judul dan sub judul, untuk menarik perhatian pembaca terhadap suatu kejadian atau pada rubrik khusus. Cetak tebal digunakan untuk menonjolkan kata penting, untuk menarik perhatian pada kata atau ungkapan.Cetak miring digunakan untuk mengutip judul suatu terbitan atau kalimat-kalimat yang dibuat orang lain.

(3) Paragraf; paragraph memberikan indikasi- indikasi tentang struktur teks.

b. Ruang Lingkup Kata (Champ Lexical); merupakan kesatuan kata dalam satu teks yang mengungkapkan ide yang sama atau mendeskripsikan fakta, realitas, pengertian yang sama. Kata-kata ini tidak harus berasal dari jenis kata yang sama ataupun sinonim, akan tetapi kata-kata ini harus memiliki kelengkapan informasi atau sudut pandang yang berbeda mengenai tematema yang dikembangkan di sekeliling kata yang dominan. Berikut merupakan contoh dari ruang lingkup kata uang (argent). 


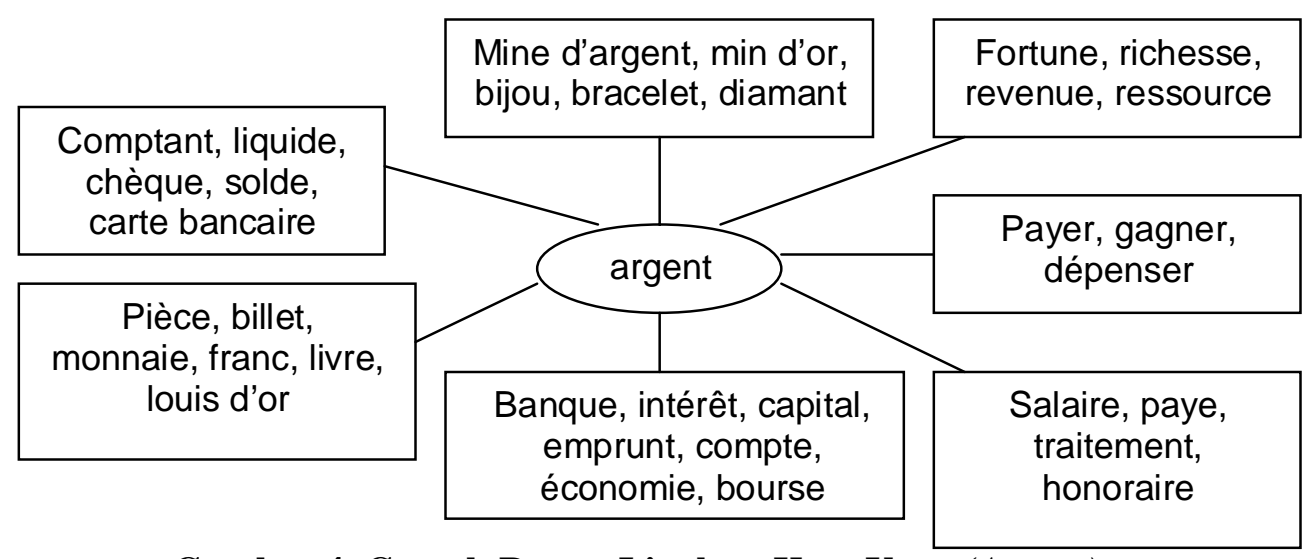

Gambar 4. Contoh Ruang Lingkup Kata Uang (Argent)

(Charnet dan Robin, 2011: 22)

c. Kata hubung atau articulator. Kata hubung atau artikulator sering disebut juga konektor kadang-kadang segera terlihat saat kata hubung tersebut terletak di awal paragraf. Melalui kata hubung, pembaca dapat mencari keterkaitan kronologis dan logis ide-ide teks. Hal ini menjadi sangat penting saat menyusun redaksi resume. Kata hubung ini meliputi:

(1) kata hubung setara, misalnya donc, et, mais, or ...

(2) kata hubung bertingkat, misalnya comme, quand, que ...

(3) lokusi adverbial, misalnya en vain, toute de suite ...

(4) lokusi konjunktif, misalnya cependant que, alors que ...

(5) preposisi, misalnya à, après, avant, depuis ...

(6) lokusi prepositif, misalnya au contraire de, jusqu'à ...

Kata-kata hubung ini kebanyakan mengungkapkan makna yang berbeda, misalnya makna waktu (valeur temporel), makna sebab-akibat (valeur consécutive), dan sebagainya.

d. Punktuasi; untuk memahami dengan baik keterkaitan kata, kelompok kata, proposisi, dan kalimat dalam teks, pembelajar bahasa Perancis benar-benar mengenal tanda-tanda punktuasi saat digunakan dalam bahasa dan makna tanda-tanda yang berbeda. Punktuasi-punktuasi ini memiliki makna ritmis dan sintaksis dan dalam tulisan menandakan modalitas wacana. Punktuasi juga merupakan reaksi peneliti (cara peneliti mengungkapkan hal-hal yang tersirat). Pada latihan menyusun resume, penggunaan punktuasi tidak hanya berguna untuk memperjelas makna tetapi juga untuk membatasi jumlah kata. Sebuah tanda punktuasi dapat menggantikan istilah kesetaraan dan ketidaksetaraan. Contoh punktuasi dalam bahasa 
Perancis yakni titik, koma, titik koma, dan sebagainya.

2. Teknik Mereduksi Isi Teks dan Menyusun Redaksi; latihanlatihannya meliputi:

a. Mengubah struktur kalimat yang kompleks; untuk dapat menyusun resume dengan baik, mahasiswa harus mengetahui cara meringkas teks asli, menghemat dan mengubah suatu kata atau ungkapan, serta mengurangi kalimat-kalimat panjang. Salah satu tekniknya adalah dengan mengubah kalimat bertingkat dengan kelompok kata.

b. Mereduksi teks asli suatu paragraf; tujuannya melatih mahasiswa mereduksi paragraf dimulai dengan reduksi terbimbing.

c. Mereduksi secara bertahap suatu paragraf; tujuannya mereduksi paragraf yang telah diresume sebelumnya.

d. Mereduksi teks pendek; tujuannya adalah untuk mencari bagian-bagian teks yang berbeda, sinonim, mencatat kata dan ide kunci, membuat resume pendek.

3. Latihan Membuat Resume; meliputi latihan:

a. Mereduksi teks dengan panjang dan kesulitan yang sedang.

b. Mereduksi teks panjang dan sulit.

\section{METODE}

Penelitian ini dilaksanakan di Jurusan Pendidikan bahasa Perancis FBS UNY di kelas Keterampilan Menulis (Expression Ecrite) IV pada semester genap tahun akademik
2010/2011 pada bulan Februari sampai April 2011.

Subjek penelitian ini adalah semua mahasiswa yang mengikuti mata kuliah Keterampilan Menulis (Expression Ecrite) IV, yang berjumlah 15 orang dan pengampu mata kuliah tersebut.

Pendekatan yang digunakan dalam penelitian ini adalah penelitian tindakan kelas. Penelitian ini disusun untuk memecahkan suatu masalah, diujicobakan dalam situasi sebenarnya dengan melihat kekurangan dan kelebihan serta melakukan perubahan yang berfungsi sebagai peningkatan. Upaya perbaikan ini dilakukan dengan melaksanakan tindakan untuk mencari jawaban atas permasalahan yang diangkat dari kegiatan seharihari di kelas. Penelitian tindakan ini termasuk dalam penelitian tindakan kelas yang berbentuk kolaboratif. Penelitian kolaboratif ini melibatkan beberapa pihak yaitu antardosen dan mahasiswa secara serentak dengan tujuan untuk meningkatkan praktik pembelajaran, menyumbang pada perkembangan teori, kolaboratif diberi makna kerja sama antardosen dengan mahasiswa untuk melakukan penelitian tindakan kelas secara bersama di kelas.

Prosedur penelitian kelas ini terdiri atas 2 siklus. Tiap siklus dilaksanakan sesuai dengan perubahan yang ingin dicapai, seperti yang telah didesain dalam variabel yang diselidiki. Untuk dapat mengetahui keterampilan menulis mahasiswa, maka diberikanlah tes diagnosis yang berfungsi sebagai awal evaluasi (initial evaluation). Observasi awal dilakukan untuk dapat mengetahui tindakan yang 
tepat yang diberikan dalam rangka meminimalkan kesalahan tersebut. Dari evaluasi dan observasi awal dapat ditetapkan bahwa tindakan yang dipergunakan untuk meningkatkan keterampilan menulis mahasiswa adalah melalui penggunaan metode task-based learning. Dengan berpatokan pada refleksi awal tersebut maka dilaksanakanlah penelitian tindakan kelas ini dengan prosedur perencanaan (planning), pelaksanaan tindakan (action), (3) observasi (observation), dan (4) refleksi (reflection) dalam setiap siklus.

Sumber data penelitian ini adalah mahasiswa dan seluruh anggota tim peneliti. Jenis data yang didapatkan adalah data kuantitatif dan data kualitatif yang terdiri dari hasil belajar, Rencana Program Pembelajaran, data hasil observasi terhadap pelaksanaan pembelajaran, dan data hasil pengisian angket oleh mahasiswa. Cara pengambilan data pada penelitian ini yakni (1) data hasil belajar diambil dengan memberikan tes kepada mahasiswa, (2) data tentang situasi belajarmengajar pada saat dilaksanakannya tindakan diambil dengan menggunakan lembar observasi, dan (3) data tentang keterkaitan antara perencanaan dengan pelaksanaan didapat dari rencana program pembelajaran dan lembar observasi.

Instrumen penelitian ini berupa tes menulis yang diberikan di awal penelitian (pretes) dan di akhir masing-masing siklus (postes), angket, catatan lapangan, lembar observasi, dan pedoman pengamatan. Indikator keberhasilan penelitian tindakan kelas ini dilihat berdasarkan keberhasilan produk dan keberhasilan proses. Indikator keberhasilan produk dilihat dari peningkatan nilai keterampilan menulis mahasiswa yakni memperoleh rata-rata nilai 7 ; sedangkan indikator keberhasilan proses dilihat dari proses pembelajaran yang dilakukan.

Validitas data pada penelitian ini menggunakan dua kriteria yaitu democratic validity dan dialogic validity. Validitas Demokratik (Democratic Validity) dan Validitas Dialogis (Dialogic Validity) ini dilaksanakan pada perencanaan Siklus I dan Siklus II. Bentuknya yakni (1) dengan melakukan diskusi dengan Kolaborator mengenai pembelajaran Keterampilan Menulis IV yang akan dilaksanakan seperti materi perkuliahan, langakah-langkah pembelajarannya, media pembelajaran yang akan digunakan, serta evaluasi pembelajaran Keterampilan Menulis IV yang berupa penyusunan résumé dan (2) dengan melakukan diskusi dengan mahasiswa mengenai materi penyusunan résumé yang belum atau kurang dikuasai mahasiswa.

Data hasil penelitian tindakan ini dianalisis dengan dua cara. Data tentang penggunaan metode pengajaran task-based learning dalam pembelajaran Expression Ecrite ditafsirkan secara kualitatif, sedangkan data keterampilan mahasiswa dalam menulis ditafsirkan secara kuantitatif.

\section{HASIL DAN PEMBAHASAN}

Penelitian ini dilakukan di kelas Expression Ecrite IV (Keterampilan Menulis IV) Jurusan 
Pendidikan Bahasa Perancis FBS Universitas Negeri Yogyakarta. Jurusan Pendidikan Bahasa Perancis FBS Universitas Negeri Yogyakarta terletak di Dusun Karangmalang Kelurahan Catur Tunggal Kecamatan Depok Kabupaten Sleman Provinsi D.I. Yogyakarta. Universitas Negeri Yogyakarta merupakan salah satu universitas eks IKIP di Indonesia yang berstatus negeri. Tempat penelitian ini adalah tempat belajar mahasiswa berupa ruang kelas.

Subjek penelitian adalah mahasiswa semester IV kelas B tahun akademik 2010/2011 sebanyak 15 orang mahasiswa. Kemampuan mahasiswa tersebut hampir sama dan semuanya berstatus tidak mengulang mata kuliah Expression Ecrite IV (Keterampilan Menulis IV). Walaupun demikian, masih ada beberapa mahasiswa yang mengikuti mata kuliah tersebut memiliki kemampuan yang kurang. Penelitian ini dilakukan oleh dosen yang sekaligus bertindak sebagai peneliti dengan satu kolaborator yang juga merupakan staf pengajar di Jurusan Pendidikan Bahasa Perancis FBS Universitas Negeri Yogyakarta.

Waktu penelitian berlangsung pada semester genap tahun pelajaran 2010/2011 antara bulan Februari sampai sampai dengan bulan April 2011. PTK ini berlangsung dalam dua siklus, siklus I terdiri atas tujuh kali pertemuan sedangkan siklus II terdiri dari lima kali pertemuan, tiap pertemuan terdiri dari 100 menit.

Penelitian ini bertujuan untuk meningkatkan keterampilan menulis mahasiswa Jurusan Pendidikan Bahasa Perancis FBS UNY melalui penggunaan metode task-based learning dalam pengajaran mata kuliah Expression Ecrite IV (Keterampilan Menulis IV). Upaya yang ditempuh adalah dengan menerapkan metode task-based learning (pembelajaran berbasis tugas) dalam pembelajaran.

Sesuai dengan tujuan tersebut, ada tiga hal yang akan dikaji dalam penelitian ini, yaitu (1) tahap persiapan: identifikasi permasalahan dan penyusunan metode pembelajaran Keterampilan Menulis IV dengan metode taskbased learning (pembelajaran berbasis tugas), (2) Implementasi tindakan: pembelajaran Keterampilan Menulis IV dengan metode taskbased learning (pembelajaran berbasis tugas), dan (3) hasil tindakan: peningkatan pembelajaran Keterampilan Menulis IV setelah diterapkannya metode task-based learning (pembelajaran berbasis tugas), dilihat dari peningkatan kualitas proses dan hasil pembelajaran.

Metode task-based learning yang diterapkan dalam proses belajar mengajar pada mata kuliah Expression Ecrite IV meliputi listing pembuatan daftar (listing), pengurutan dan penyortiran (ordering and sorting), pembandingan (comparing), pemecahan masalah (problem solving), dan tugas kreatif (creative tasks). penelitian kelas ini terdiri atas 2 siklus. Tiap siklus dilaksanakan sesuai dengan perubahan yang ingin dicapai, seperti yang telah didesain dalam variabel yang diselidiki. Untuk dapat mengetahui keterampilan menulis mahasiswa, maka diberikanlah tes diagnosis yang berfungsi sebagai awal evaluasi (initial evaluation). Observasi awal 
dilakukan untuk dapat mengetahui tindakan yang tepat yang diberikan dalam rangka meminimalkan kesalahan tersebut. Dari evaluasi dan observasi awal dapat ditetapkan bahwa tindakan yang dipergunakan untuk meningkatkan keterampilan menulis mahasiswa adalah melalui penggunaan metode task-based learning.

Dengan berpatokan pada
refleksi awal tersebut maka
dilaksanakanlah penelitian tindakan
kelas ini dengan prosedur (1)
perencanaan (planning), (2)
pelaksanaan tindakan (action), (3)
observasi (observation), dan (4)
refleksi (reflection) dalam setiap
siklus. Secara rinci prosedur
penelitian tindakan dapat dijabarkan
sebagai berikut.

\section{Perencanaan}

Adapun kegiatan yang dilakukan dalam tahap perencanaan ini adalah sebagai berikut:

1. Menentukan materi kuliah yang akan diberikan yakni menyusun resumé, dengan sub materi Kontak Awal dengan Teks, Teknik Mereduksi Isi Teks, dan Latihan Membuat Resume.

2. Membuat skenario pembelajaran dengan menggunakan berbagai pola pembuatan tugas.

3. Membuat lembar observasi: untuk melihat bagaimana kondisi belajar-mengajar di kelas ketika rancangan tersebut diaplikasikan.

4. Membuat alat bantu mengajar yang diperlukan dalam rangka optimalisasi keterampilan menulis mahasiswa.

5. Mempersiapkan 2 alat evaluasi untuk melihat apakah keterampilan menulis mahasiswa sudah meningkat.

\section{Pelaksanaan Tindakan}

Pada penelitian ini, yang bertindak sebagai pengajar sekaligus peneliti adalah peneliti sendiri yang juga dosen di Jurusan Pendidikan Bahasa Perancis Fakultas Bahasa dan Seni Universitas Negeri Yogyakarta. Pemantauan melalui observasi dilakukan oleh seorang kolaborator yang juga dosen di Jurusan Pendidikan Bahasa Perancis Fakultas Bahasa dan Seni Universitas Negeri Yogyakarta. Kegiatan yang dilaksanakan dalam tahap ini adalah melaksanakan skenario pembelajaran yang telah direncanakan yang meliputi :

1. Pada setiap jam perkuliahan Keterampilan Menulis (Expression Ecrite) IV (sesuai jadwal) dosen mengajar dengan materi sesuai dengan silabus mata kuliah Keterampilan Menulis (Expression Ecrite) IV, serta sesuai dengan Rancangan Program Pembelajaran (RPP) yang telah dibuat.

2. Pada setiap pembelajaran tersebut, dosen menggunakan metode task-based learning. Jenis-jenis tugas yang diterapkan dalam proses belajar mengajar pada mata kuliah Expression Ecrite IV meliputi listing pembuatan daftar (listing), pengurutan dan penyortiran (ordering and sorting), pembandingan 
(comparing), pemecahan masalah (problem solving), dan tugas kreatif (creative tasks).

3. Dosen bersama mahasiswa membahas tugas-tugas yang dianggap sukar oleh mahasiswa.

4. Kolaborator dan dosen Keterampilan Menulis (Expression Ecrite) IV mengadakan observasi setiap kali proses pembelajaran berlangsung secara bergantian.

5. Dosen memberikan angket kepada mahasiswa pada akhir siklus kedua untuk melihat sampai sejauh mana keberhasilan proses pembelajaran keterampilan menulis bahasa Perancis ini.

6. Merevisi tugas-tugas, baik dalam waktu pelaksanaan, lama, jenis materi, maupun taraf kesukarannya, berdasarkan hasil obsevasi. Pelaksanaannya melalui diskusi antara dosen dan kolaborator.

7. Melaksanakan pembelajaran untuk siklus ke II. Dengan tindakan sesuai hasil revisi/refleksi dari siklus I.

8. Mengadakan evaluasi/tes.

\section{Observasi}

$$
\begin{aligned}
& \text { Pada tahap ini dilaksanakan } \\
& \text { proses observasi terhadap } \\
& \text { pelaksanaan tindakan dengan } \\
& \text { menggunakan lembar observasi yang } \\
& \text { telah dibuat. Kegiatan pada tahap ini } \\
& \text { meliputi: }
\end{aligned}
$$

2. Dosen menyuruh semua mahasiswa untuk mengerjakan lembar evaluasi dan angket sikap mahasiswa terhadap pembelajaran Expression Ecrite IV.

3. Dosen mengadakan penilaian terhadap hasil pekerjaan mahasiswa.

\section{Refleksi}

Hasil yang didapatkan dalam tahap observasi dikumpulkan serta dianalisis dalam tahap ini. Dari hasil observasi, pengajar dapat merefleksikan diri dengan melihat data observasi apakah kegiatan yang telah dilakukan telah dapat meningkatkan keterampilan menulis mahasiswa. Data dari lembar observasi juga dapat dipergunakan sebagai acuan bagi pengajar untuk dapat mengevaluasi dirinya sendiri. Hasil analisis data yang dilaksanakan dalam tahap ini akan dapat dipergunakan sebagai acuan untuk merencanakan siklus berikutnya.

Penelitian ini terdiri atas empat tahap yakni merumuskan masalah dan merencanakan tindakan, melaksanakan tindakan dan pengamatan, refleksi hasil pengamatan, dan revisi perencanaan untuk pengembangan selanjutnya. Selama pembelajaran, mahasiswa dibagi dalam 5 dan 7 kelompok dan tiap kelompok terdiri atas 2 - 3 mahasiswa dengan kemampuan heterogen.

Pada setiap kegiatan pembelajaran Expression Ecrite IV mahasiswa mengerjakan tugas-tugas yang diberikan dosen yang berupa penyusunan résumé teks dalam bahasa Perancis. Keaktifan siswa dalam kelompoknya memegang 
peranan penting dalam penerapan metode task-based learning dalam proses belajar mengajar pada mata kuliah Expression Ecrite IV. Dalam kegiatan pembelajaran, mahasiswa yang memiliki minat tinggi cenderung lebih aktif, tetapi ada pula mahasiswa yang tidak tertarik dan cenderung menggantungkan pada anggota kelompoknya maupun pada anggota kelompok lain. Sebelum kegiatan perkuliahan dimulai, dosen menyiapkan alat dan media yang akan digunakan serta memberikan penjelasan mengenai materi perkuliahan. Pada awal pembelajaran dosen memberikan apersepsi kemudian memunculkan permasalahan dari apersepsi tersebut. Hal ini dilakukan agar menarik perhatian mahasiswa. Permasalahan yang ada selanjutnya dipecahkan oleh mahasiswa melalui pengerjaan tugas yang diberikan dosen.

Penggunaan metode taskbased learning dalam pengajaran mata kuliah Expression Ecrite IV dapat mengurangi kepasifan mahasiswa dan akan dapat memacu peningkatan partisipasi mahasiswa dalam kegiatan belajar yang bermakna. Kegiatan belajar yang efektif dan bermakna hanya dapat berlangsung apabila dapat dibangun hubungan antara konsep-konsep baru dengan konsep-konsep yang terbentuk di dalam struktur kognitif siswa. Selain itu juga meningkatkan perhatian siswa untuk melibatkan diri dalam kegitan pembelajaran.

Kegiatan pembelajaran dengan menggunakan metode taskbased learning memperbanyak penguatan (reinforcement) yang diterima mahasiswa. Pembelajaran dengan menggunakan metode task- based learning meningkatkan keterlibatan mahasiswa serta dapat meningkatkan motivasi belajar mahasiswa. Pembelajaran Expression Ecrite $I V$ dengan menggunakan metode task-based learning akan mendukung terwujudnya sistem pembelajaran yang efektif dan efisien maka prestasi belajar Expression Ecrite $I V$ akan meningkat. Dengan pemberian tugas-tugas, mahasiswa akan mendapatkan kemudahan dalam menyusun résumé teks dalam bahasa Perancis dan teknik-teknik yang telah mereka kuasai tersebut tidak mudah untuk dilupakan. Dengan adanya penguasaan teknik-teknik penyusunan résumé teks dalam bahasa Perancis yang baik pada diri mahasiswa dan dengan adanya kemudahan mahasiswa di dalam belajar maka prestasi belajar Expression Ecrite IV mahasiswa akan menjadi lebih baik.

Untuk menghindari adanya kekeliruan dalam pemahaman teknik-teknik penyusunan résumé teks dalam bahasa Perancis maka para mahasiswa dituntut untuk mengetahui secara pasti apakah jawaban temannya itu benar atau salah. Situasi seperti inilah yang dengan segera dapat menimbulkan diskusi (tanya - jawab) antara dosen dan mahasiswa, sehingga keterlibatan mahasiswa dalam kegiatan pembelajaran Expression Ecrite IV akan meningkat dan terjadinya komunikasi dua arah tersebut berarti mengurangi kepasifan mahasiswa serta dapat meningkatkan motivasi belajar Expression Ecrite IV mahasiswa.

Selain itu, dengan digunakannya metode task-based learning terjadi peningkatan prestasi 
belajar Expression Ecrite $I V$. Peningkatan prestasi ini ditandai dengan rerata skor postes 6,3 pada siklus I meningkat menjadi 7,2 pada siklus II.

Adapun hasil angket respon mahasiswa terhadap pembelajaran Keterampilan Menulis (Expression Ecrite) diperoleh kesimpulan berikut ini.

1. Sebagian besar mahasiswa $(93,3 \%)$ tidak setuju bahwa pembelajaran Keterampilan Menulis (Expression Ecrite) kurang penting dibandingkan pembelajaran mata kuliah lainnya.

2. Semua mahasiswa menyatakan bahwa pembelajaran Keterampilan Menulis (Expression Ecrite) bermanfaat untuk melatih daya nalar dan melatih menulis dengan baik.

3. $93,3 \%$ mahasiswa berpendapat bahwa memahami bahasa tulis sulit, $6,7 \%$ mahasiswa berpendapat sangat sulit, dan tak seorang pun yang berpendapat mudah.

4. Dalam pembelajaran Keterampilan Menulis (Expression Ecrite) IV, 20\% mahasiswa berpendapat bahwa dosen kurang melibatkan mahasiswa, $40 \%$ mahasiswa berpendapat bahwa dosen cukup melibatkan mahasiswa, dan $40 \%$ mahasiswa berpendapat bahwa dosen melibatkan mahasiswa secara aktif.

5. $60 \%$ mahasiswa berpendapat bahwa setiap selesai mengajar dosen selalu

\author{
menanyakan perasaan/kesan \\ mahasiswa terhadap \\ pembelajaran yang baru saja \\ berlangsung dan $40 \%$ \\ mahasiswa berpendapat \\ bahwa dosen kadang-kadang \\ melakukannya.
}

\section{SIMPULAN DAN SARAN}

Penggunaan metode pembelajaran berbasis tugas (task based learning) dalam pembelajaran Keterampilan Menulis IV dapat meningkatkan keterampilan menulis mahasiswa di Jurusan Pendidikan Bahasa Perancis FBS UNY. Peningkatan tersebut terlihat pada pemahaman dan penguasaan materi mahasiswa yang menjadi lebih baik dari sebelumnya. Hal ini dibuktikan dengan peningkatan nilai rata-rata yang diperoleh mahasiswa berdasarkan hasil pretes 5,6 meningkat menjadi 6,3 pada postes siklus I dan menjadi 7,2 pada postes siklus II.

Selain itu, terjadi pula peningkatan proses pembelajaran Keterampilan Menulis IV. Hal tersebut ditandai dengan berkurangnya kepasifan mahasiswa dan peningkatan partisipasi mahasiswa dalam kegiatan pembelajaran yang bermakna.

Penguasaan materi dan peningkatan proses pembelajaran tersebut disertai pula dengan peningkatan apresiasi dan sikap yang baik pada diri mahasiswa. Berdasarkan hasil angket yang diberikan dan hasil wawancara kepada mahasiswa, sebagian besar mahasiswa menyatakan menjadi lebih menyukai pembelajaran Keterampilan Menulis dengan 
menggunakan metode pembelajaran berbasis tugas (task based learning).

Ada beberapa saran yang diajukan kepada dosen bahasa Perancis, mahasiswa, dan peneliti yang lain.

1. Kepada Dosen Bahasa Perancis

Pelaksanaan kegiatan pembelajaran yang efektif sangat dipengaruhi oleh gaya dan sikap dosen terhadap keadaan kelas. Untuk mendapatkan hasil seperti yang diharapkan, dosen hendaknya mampu mengembangkan pola-pola pembelajaran dan menerapkan rancangan pembelajaran yang sesuai dengan keadaan mahasiswa.

2. Kepada Mahasiswa

Sebagai penerus pembangunan bangsa, hendaknya selalu meningkatkan potensi diri terutama yang berkaitan dengan program studi yang dimasukinya serta dapat melaksanakan cara belajar bahasa Perancis yang benar dan efektif misalnya dengan lebih berpartisipasi secara aktif saat proses belajarmengajar berlangsung, membuat rencana belajar, melakukan belajar kelompok, memperbanyak mengerjakan latihan soal-soal, belajar dengan teratur, sehingga kemungkinan untuk mencapai prestasi belajar bahasa Perancis yang maksimal akan lebih besar khususnya pada mata kuliah keterampilan menulis.

3. Kepada Universitas

Dalam rangka perbaikan pembelajaran, hendaknya universitas memberikan dorongan serta menfasilitasi para dosen yang akan mengadakan penelitian tindakan kelas.

\section{UCAPAN TERIMA KASIH}

Peneliti mengucapkan terima kasih kepada Prof. Dr. Suminto A. Sayuti yang telah membimbing peneliti dalam melakukan penelitian ini. Peneliti juga mengucapkan terima kasih kepada Dr. Roswita L. Tobing, M.Hum. dan Dra. Siti Perdi Rahayu, M.Hum. yang telah meluangkan waktu untuk berdiskusi dengan peneliti demi kesempurnaan penelitian ini.

\section{PUSTAKA RUJUKAN}

Charnet, C. dan Robin-Nipi, J. 2011. Rédiger Un Résumé, Un Compte Rendu, Une Synthèse. Paris: Hachette Livre.

Nunan, D. 2005. Design Task for the Communication Classroom. Cambridge: Cambridge University Press.

Tagliante, C. 2008. Techniques de Classe "La Classe de Langue”. Paris: CLE International.

Willis, J. 2010. A Framework for Task-Based Learning. Edinburgh: Longman. 